\title{
The assessment of lining structure impact on radon behaviour inside selected underground workings under the cour d'honneur of Książ castle
}

\author{
Lidia Fijałkowska-Lichwa ${ }^{1}$ (D)
}

Received: 13 June 2020 / Accepted: 13 September 2020 / Published online: 26 September 2020

(c) The Author(s) 2020

\begin{abstract}
The results based on 2-year long measurements 01 Jan. 2016-2031 Dec. 2017 have been used for discussing the influence of tunnel lining on the size of ${ }^{222} \mathrm{Rn}$ activity concentration and the impact of the employed rock mass insulation on natural convective air exchange. In April, air movement started when the temperature was at least $7{ }^{\circ} \mathrm{C}$ lower than the mean inside. Between May and October, an increase to $9{ }^{\circ} \mathrm{C}$ above the underground temperature resulted in an increase of radon concentration. An unconstrained convection process did not start until November and it continued until the end of March. The reinforced concrete lining insulated the fractured and absorptive rock mass. The roof and the sidewall lining had little impact on air movement process.
\end{abstract}

Keywords Continuous ${ }^{222} \mathrm{Rn}$ measurements $\cdot$ Convective air movement · Transitional periods $\cdot$ Underground corridors . Underground construction $\cdot$ Reinforced concrete lining

\section{Introduction}

Being a natural source of ionizing radiation, $\operatorname{radon}\left({ }^{222} \mathrm{Rn}\right)$ is one of the basic radiation hazards occurring in man's natural life and work environment [1-3].

As demonstrated by statistics, people staying inside enclosed spaces well isolated from the atmosphere and frequently lacking ventilation, such as underground engineering structures including underground tour routes, mine adits, caves, underground laboratories, castle vaults, and mines are at risk of receiving as much as $95 \%$ of the effective dose coming from radon [4-26, 85, 86].

The number of such spaces in Poland is growing steadily. A large proportion of the about 200 currently existing ones $[5-7,20-24,32,33,71,85]$ are underground workplaces situated at small depths (up to $200 \mathrm{~m}$ below ground level) in radon prone areas characterized by increased concentrations of radium $\left({ }^{226} \mathrm{Ra}>30 \mathrm{~Bq} / \mathrm{m}^{3}\right)$, the parent source of radon present in subsoil [27-34]

Lidia Fijałkowska-Lichwa

lidia.fijalkowska-lichwa@pwr.edu.pl

1 Wrocław, Poland
Due to its gaseous state, radon $\left({ }^{222} \mathrm{Rn}\right)$ readily migrates from the structure of rocks building the subsoil into both open and enclosed spaces (especially these situated immediately under the earth's surface). Radon's ability to accumulate, especially in natural cavities within rock masses and their man-made counterparts such as mines, adits, castle vaults or underground laboratories, is due, among other reasons, to its high density-over 7 times as high as the specific weight of the atmospheric air [33-35].

The migration (escape) process, caused mainly by convection and, to a lesser extent, by diffusion and advection, is facilitated by sedimentary, tectonic and erosion structures found in the rock mass, e.g. fissures, fractures and discontinuity planes (faults). Their directional strike and the availability of geofluids $\left(\mathrm{CO}_{2}\right.$ or groundwater) quite often increase the speed and extend the route of this radioactive gas transport [8-10, 36-43].

One of the proposed solutions providing protection against the effects of radon migration and its increased exhalation in enclosed spaces is insulating and increasing air tightness by reducing porosity and permeability of building construction and materials [44-57]. In underground facilities both the ground, the roof and side walls of a given space should be insulated. Considering the above observations, the author assessed the effectiveness of such a solution and 
whether reinforced concrete lining, being a structural element of underground workings, can provide insulation and thereby significantly reduce radon concentration inside an underground space.

\section{Study area}

The object of research are two underground corridors in adit no. 2, one of the main entrances to the underground system under the cour d'honneur of Książ castle. They were drilled as a part of mining and construction works launched in 1943 within the wider project called Riese connected with the Third Reich takeover of Książ castle and its reconstruction and adaptation for a government facility. The work was done by prisoners from the concentration camp Gross-Rosen [58-62]. Since the 1970s, the research site has been a part of an underground geodynamic laboratory [65-70] and as such it is an underground workplace where occupational activity, as defined by Atomic law [63] recently amended in compliance with the EU regulations [64], is conducted in radiation exposure conditions $[1,2,63,64]$.
The system of workings is located $50 \mathrm{~m}$ below the level of the cour d'honneur and it is made up of four adits interconnected by numerous underground corridors and chambers. The total length of the underground system of Książ castle is $950 \mathrm{~m}$, its surface area- $3.200 \mathrm{~m}^{2}$, and the capacity- $13.000 \mathrm{~m}^{3}$ [60].

The two sections of the workings selected for investigations are an essential part of the underground system of Książ castle, which is not accessible to visitors (Fig. 1). One section is a concrete-lined corridor being a part of the main passageway. It is located to the left of the fork of the main gallery, a part of the underground tour route since October 2018. In the section chosen for research, the adit roof was inserted in the corridor roof to form one common profile. The corridor cross-section is close to an ellipsis in shape. Its length, starting from the crossing, is c. $35 \mathrm{~m}$, the width-c. $3.7 \mathrm{~m}$, and the height $-\mathrm{c} .4 .8 \mathrm{~m}$. At the height of about 2.7$3.2 \mathrm{~m}$ over the floor, steel reinforcement bars were concreted in the walls. They were meant to facilitate the construction of another roof (inter-roof), dividing the corridor into the main part and the 'technical' space. All the walls and the roof of the corridor were made in the reinforced concrete lining, but no concrete floor was executed. The tunnel lining

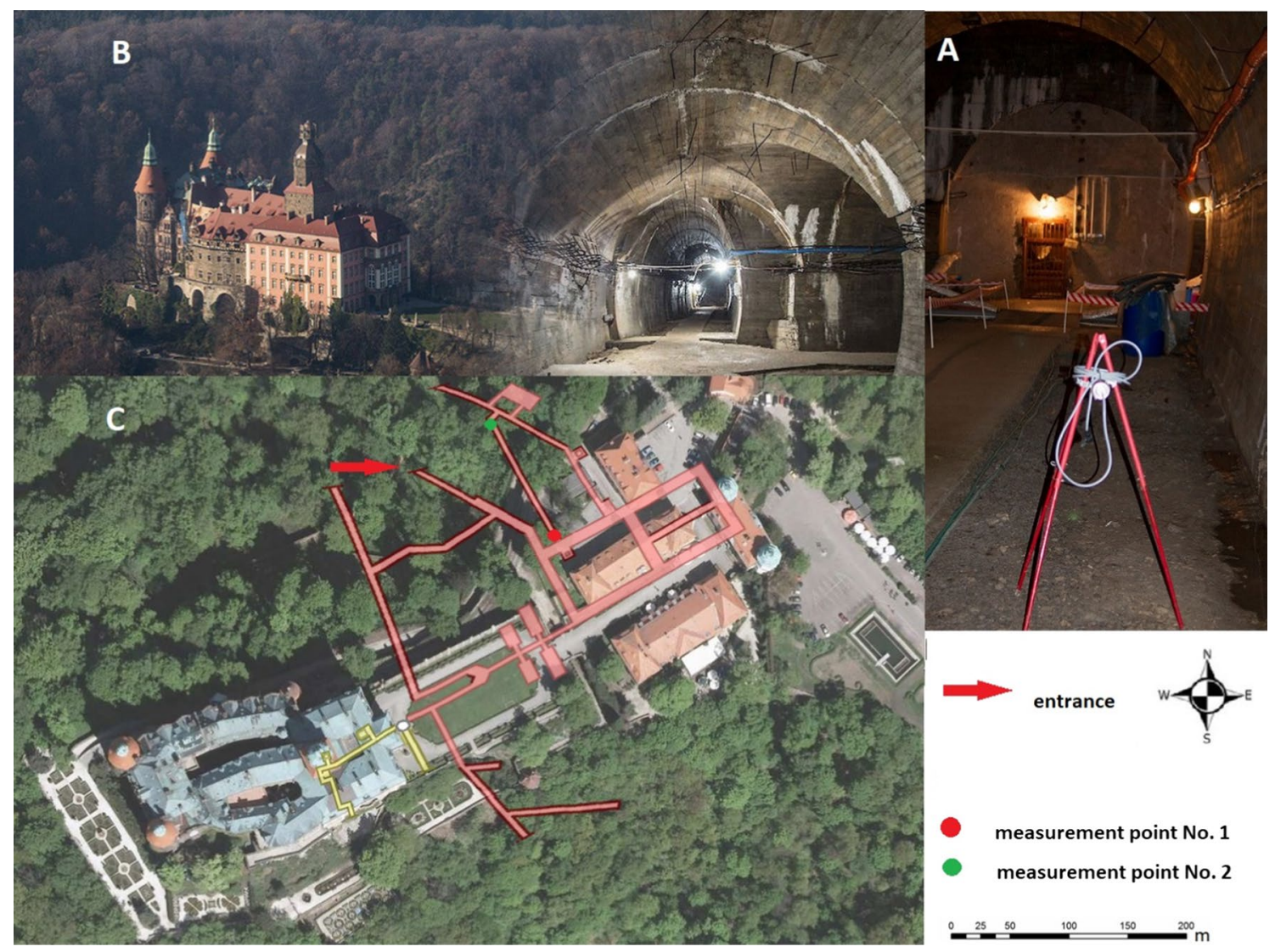

Fig. 1 Plan of the distribution of measurement points in the undergrounds under the cour d'honneur of Książ castle (C) and view of an underground excavation with reinforced concrete lining (B) were placed SRDN-3 No. 3 probe (A) (based on 69, 87] 
is a structural element. Its role was to enhance the supporting capacity and ensure the stability of the workings. The underground corridors of Książ castle were provided with lining because of their large cross-sections and difficult geological and mining conditions (numerous fractures, faults, and weathered rock). Additionally, it was meant to additionally protect the workings which were intended as a bomb shelter. The layer of concrete directly adhering to the rock mass improved the self-bearing capacity of the workings thus reducing the load on the lining structure. Another function of the chosen lining structure was to prevent the release of gases or water from the ambient rocks into the space. The type of lining was also adjusted to the extent of stress-relief zone and the displacements of rocks surrounding the excavations. When choosing the lining structure parameters, the angle of internal friction and rock cohesion, as well as the humidity of the fractured rock mass were taken into account [59-61, 72-76]. Roughly halfway along the side corridor, there is a drilled entrance to the other studied space. It was left without lining and blind-ended (most likely due to a cave-in resulting from a natural rock fall). Likewise the other corridors, it was executed with a slight dip towards the exit. The mining works carried out in this space were much less advanced (it is not profiled). Major dislocation zones and a lot of outcrops of fault gouge are visible here. In this part of inaccessible tunnels, the tectonic fault is the most conspicuous. The rocks are cut by minor fractures with small depths, large fracture zones with depths reaching dozens of centimetres, as well as systems of fractures occurring next to each other in a small area $[60,77,78]$.

The selected research object is characterized by unforced ventilation (based on the principles of convection) and timevarying (subject to seasonal and short-time variation) values of ${ }^{222} \mathrm{Rn}$ activity concentration. The site interior is characterized by stable temperature (averaging $10.2^{\circ} \mathrm{C}$ ) and humidity $(100 \%)[23,71]$.

\section{History and geology}

The first measurements of ${ }^{222} \mathrm{Rn}$ activity concentration in the tunnels under Książ castle were launched in 2014. The obtained results indicate that variation in the recorded values of ${ }^{222} \mathrm{Rn}$ activity concentration is influenced chiefly by the process of natural convective air exchange, which is constrained in transitional periods occurring between spring and autumn. Analyses are still being conducted to evaluate the influence of geodynamic phenomena induced by strike-slip movements in the dislocation zone, which can be reflected by changes in the size of radon flux (gas exhalation) from fractured and weathered sedimentary rocks.

So far, no research has been conducted into the assessment of the possible role of lining structures, being the principal structural element ensuring the stability of underground workings, as a barrier limiting the size of radon exhalation.

The research object is located in the underground part of a castle and palace complex, Poland's third (after Malbork and Wawel) largest architectural monument of this kind. It is situated on a cliff in the Wałbrzych Foothills, in a meander of the river Pełcznica. The underground workings were carved in the slopes of hills cutting the Pełcznica and the Szczawnik valley into two floristic reserves: the Pełcznica Gorge and the Szczawnik Gorge (Fig. 1; [61]).

In geological terms, these workings are situated in the central part of the Świebodzice basin structural unit (ŚU) intersected by a network of numerous faults running along its borders with the neighbouring units: the faults of Struga (to the south) and Szczawienko (to the west), and the Sudetic marginal fault to the east (Fig. 2; [79-82]). The Świebodzice depression is filled with Lower-Carboniferous and, secondarily, Upper Devonian deposits. These are sedimentary rocks classified as parts of the formation of Pogorzała, Pełcznica, Chwaliszów and Książ. Its northern part is made up of overthrusts of the Kaczawa complex metamorphic rocks [70].

\section{Methods}

The aim of the paper is the assessment of the role of reinforced concrete lining structure as a barrier insulating the workings from increased radon exhalation, including the assessment of its influence on the character and pattern of changes in ${ }^{222} \mathrm{Rn}$ concentration activity and on the natural convective process of air exchange in the studied space.

The analysis was carried out during two measurement periods lasting uninterruptedly from 1 January 2016 to 31 December 2016 and from 01 January 2017 to 31 December 2017 , when continuous measurements of ${ }^{222} \mathrm{Rn}$ activity concentration were conducted.

To equalize the durations of the measurement cycles in 2016 and 2017, 29 February 2016 was excluded from the investigation. The analysis was conducted for two measurement points. One of them was set up in an excavation secured with reinforced concrete lining structure. The other one was regarded as representative of ${ }^{222} \mathrm{Rn}$ activity concentration values recorded in a natural, fractured rock mass visible in one of the selected corridors under Książ.

The convection process and its effect on the size of ${ }^{222} \mathrm{Rn}$ activity concentration is demonstrated by daily changes in ${ }^{222} \mathrm{Rn}$ activity concentration occurring in socalled transitional periods lasting from April to early October. The data on the daily average temperature of the atmospheric air at Książ, recorded from April to October 2017, was obtained from the website of the weather archive of Wałbrzych city [83]. 


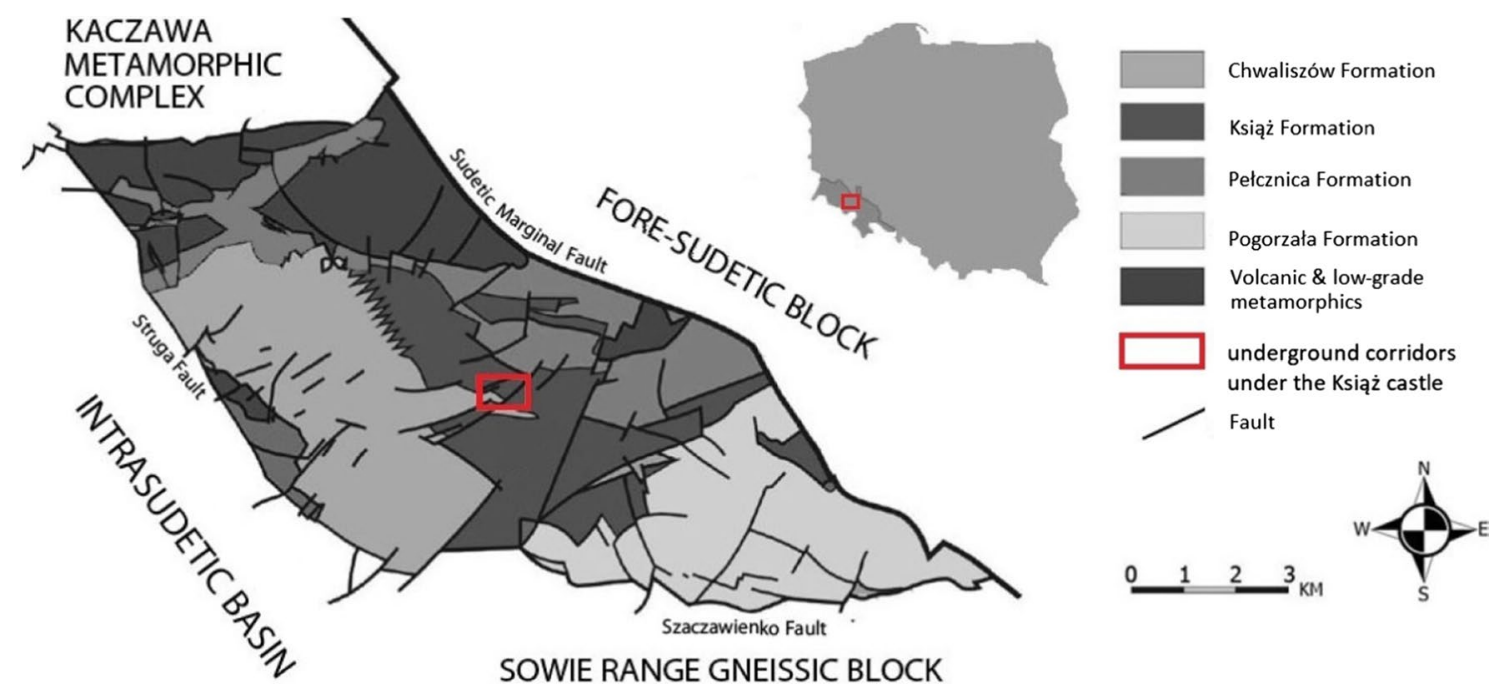

Fig. 2 Location of the undergrounds under the cour d'honneur of Książ castle on a simplified geological map of the Sudetes (based on 88)

The obtained results have been compiled and compared (Figs. 3, 4, 5, 6, 7, 8, Tables 1, 2). The measurement results are also discussed in the context of the currently amended Polish radiological protection regulations [64].

\section{Radon measurements}

Measurements of ${ }^{222} \mathrm{Rn}$ activity concentration were conducted by means of two SRDN-3 probes. Each of them was installed in one of the two corridors in the underground system selected for the research. The probes are Polishmade devices equipped with semiconductor detectors frequently used in long-term measurements conducted in underground spaces $[21,22,84,85]$ including the tunnels under the cour d'honneur of Książ castle [24, 71]. The construction and the operation principle of the SRDN-3 probe have been repeatedly discussed in publications, and its detailed description was included in the work by Przylibski and co-authors [84]. The ${ }^{222} \mathrm{Rn}$ activity concentration detection thresholds for SRDN-3 probes range
Fig. 3 Pattern of ${ }^{222}$ Rn activity concentration changes with visible seasons registered throughout all the measurement period between 1 January and 31 December 2016 at two measurement points in underground corridors under the cour d'honneur of Książ castle. Graph explanation: straight line-average value of ${ }^{222} \mathrm{Rn}$ activity concentration with moving average fitting

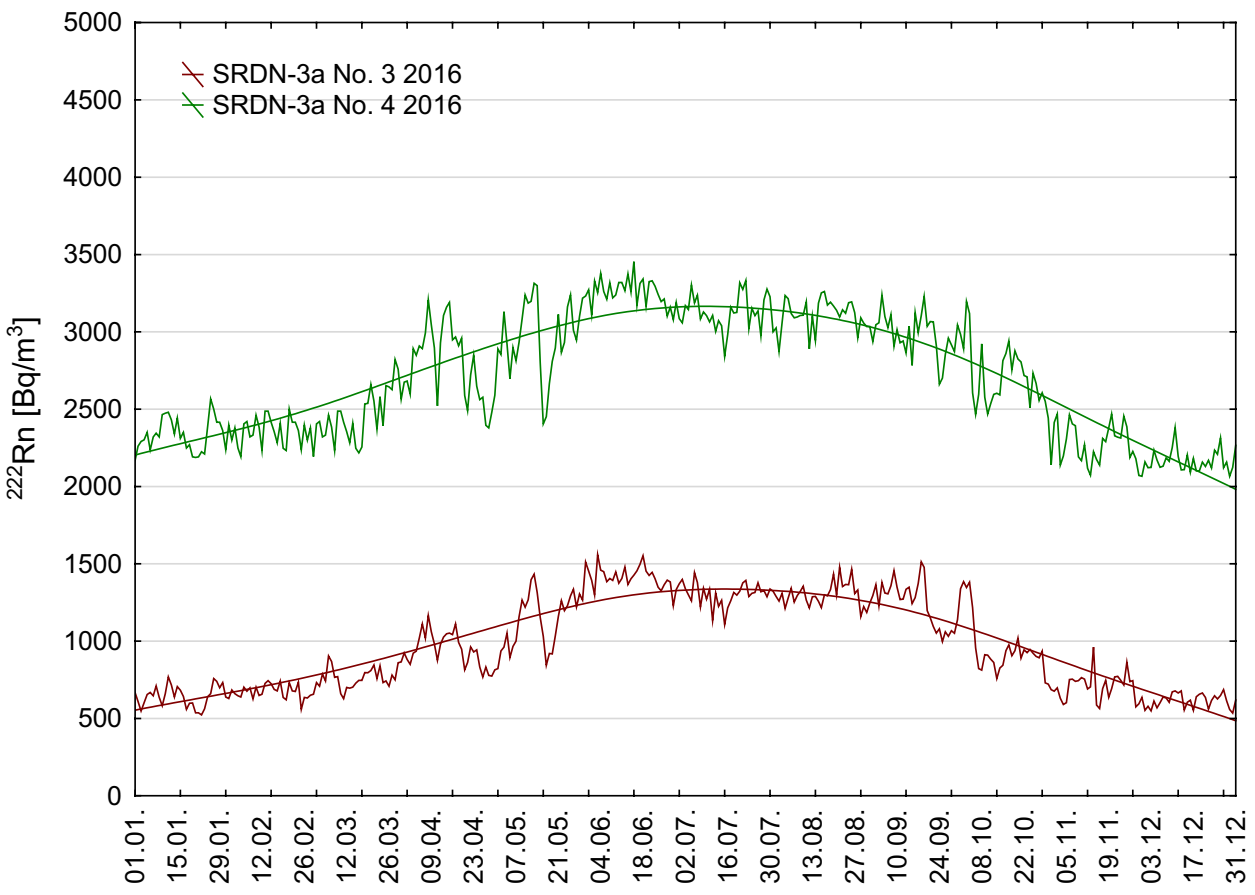

Date 
Fig. 4 Pattern of ${ }^{222} \mathrm{Rn}$ activity concentration changes with visible seasons registered throughout all the measurement period between 1 January and 31 December 2017 at two measurement points in underground corridors under the cour d'honneur of Książ castle. Graph explanation: straight line-average value of ${ }^{222} \mathrm{Rn}$ activity concentration with moving average fitting. SRDN-3a the same SRDN-3 device, the letter indicates later production, the designations used in parallel

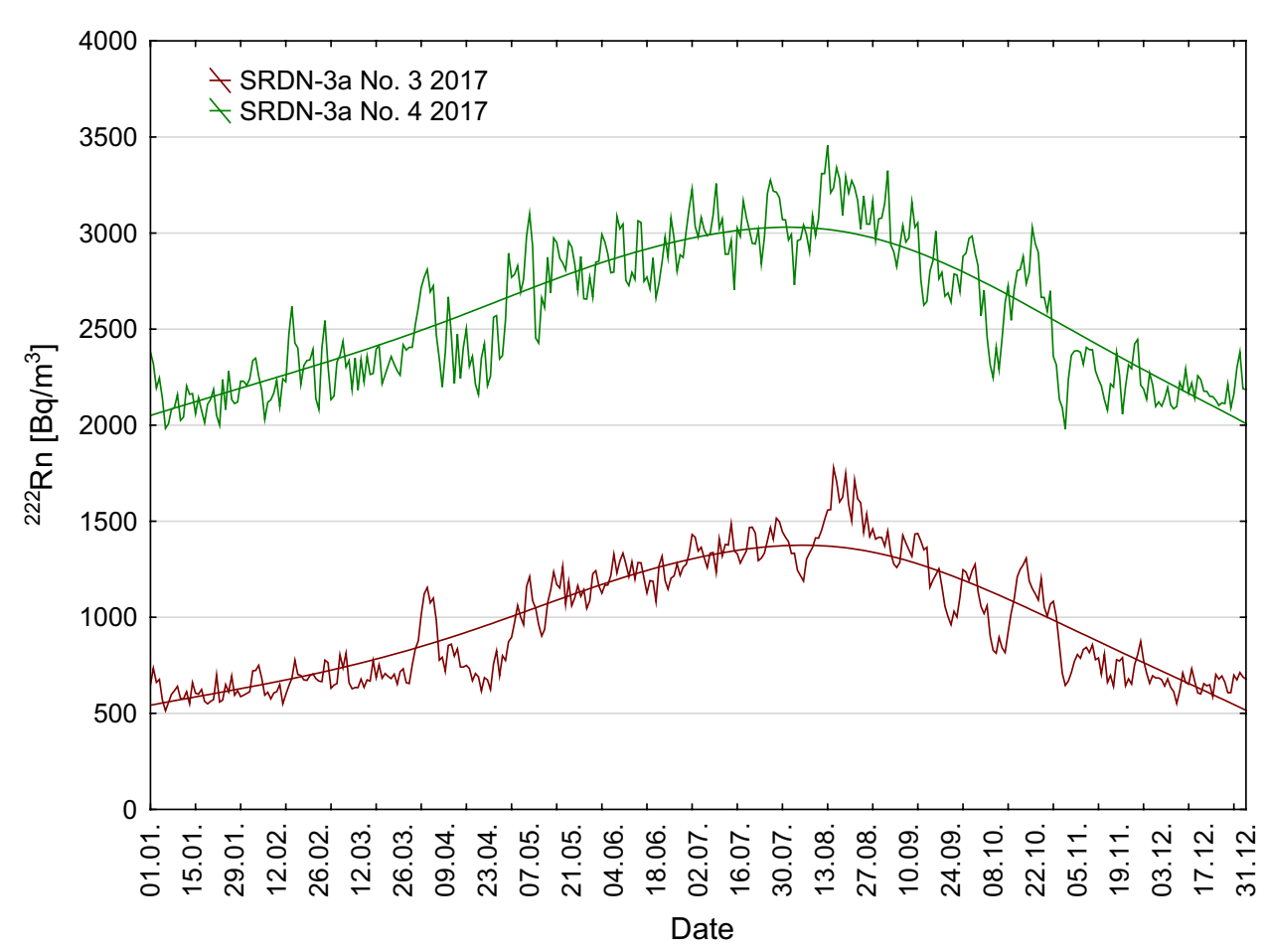

Fig. 5 Pattern of diurnal ${ }^{222} \mathrm{Rn}$ activity concentration changes in comparison with inside and outside temperature registered in April, June and September 2017 on first measuring point. Graph explanation: dashed line-average value of ${ }^{222} \mathrm{Rn}$ activity concentration with moving average fitting. $\mathrm{R}$-right y axis, L-left y axis. SRDN-3a the same SRDN-3 device, the letter indicates later production, the designations used in parallel

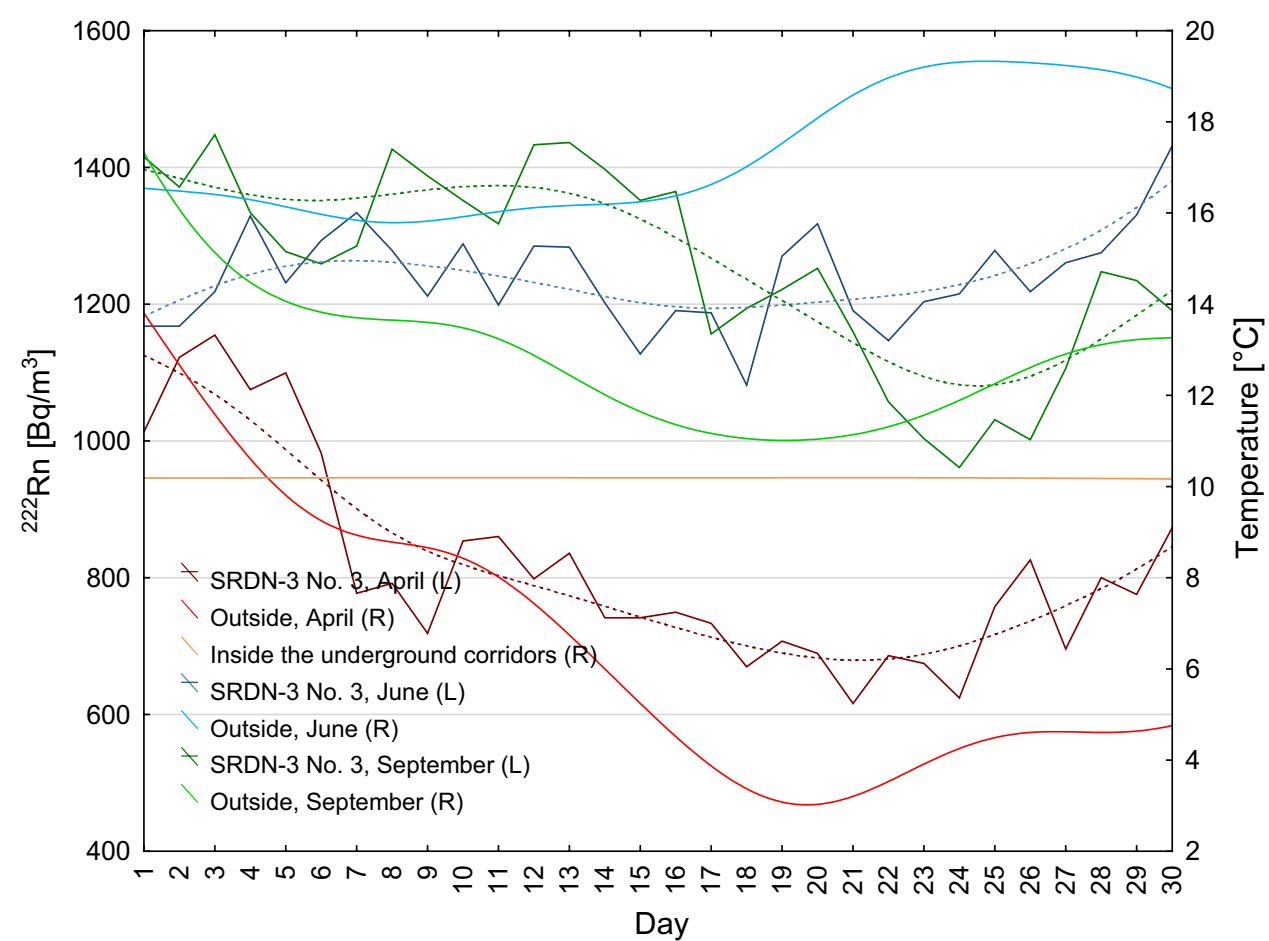

from 90 to $100 \mathrm{~Bq} / \mathrm{m}^{3}$. The maximum measurable value of ${ }^{222} \mathrm{Rn}$ activity concentration for a SRDN-3 probe is $157 \mathrm{MBq} / \mathrm{m}^{3}$. The measurement uncertainty depends on the size of the measured ${ }^{222} \mathrm{Rn}$ activity concentration and it may range from 21 to $39 \%$. The higher the value of ${ }^{222} \mathrm{Rn}$ activity concentration, the lower the measurement concentration, starting from $20 \%$ for ${ }^{222} \mathrm{Rn}$ values of the order of $1000 \mathrm{~Bq} / \mathrm{m}^{3}$ to even $7 \%$ for the value in the range of $5000-10,000 \mathrm{~Bq} / \mathrm{m}^{3}[23,84]$.

The semiconductor SRDN-3 detectors were positioned on tripods at the height of $1 \mathrm{~m}$ over the floor of each corridor (Fig. 1). 
Fig. 6 Pattern of diurnal ${ }^{222} \mathrm{Rn}$ activity concentration changes in comparison with inside and outside temperature registered in April, June and September 2017 on second measuring point. Graph explanation: dashed line-average value of ${ }^{222} \mathrm{Rn}$ activity concentration with moving average fitting. $\mathrm{R}$-right y axis, $\mathrm{L}$ - left y axis
Fig. 7 Pattern of diurnal ${ }^{222} \mathrm{Rn}$ activity concentration changes in comparison with inside and outside temperature registered in May, July, August and October 2017 on first measuring point. Graph explanation: dashed line-average value of ${ }^{222} \mathrm{Rn}$ activity concentration with moving average fitting. $\mathrm{R}$-right y axis, $\mathrm{L}$ - left y axis

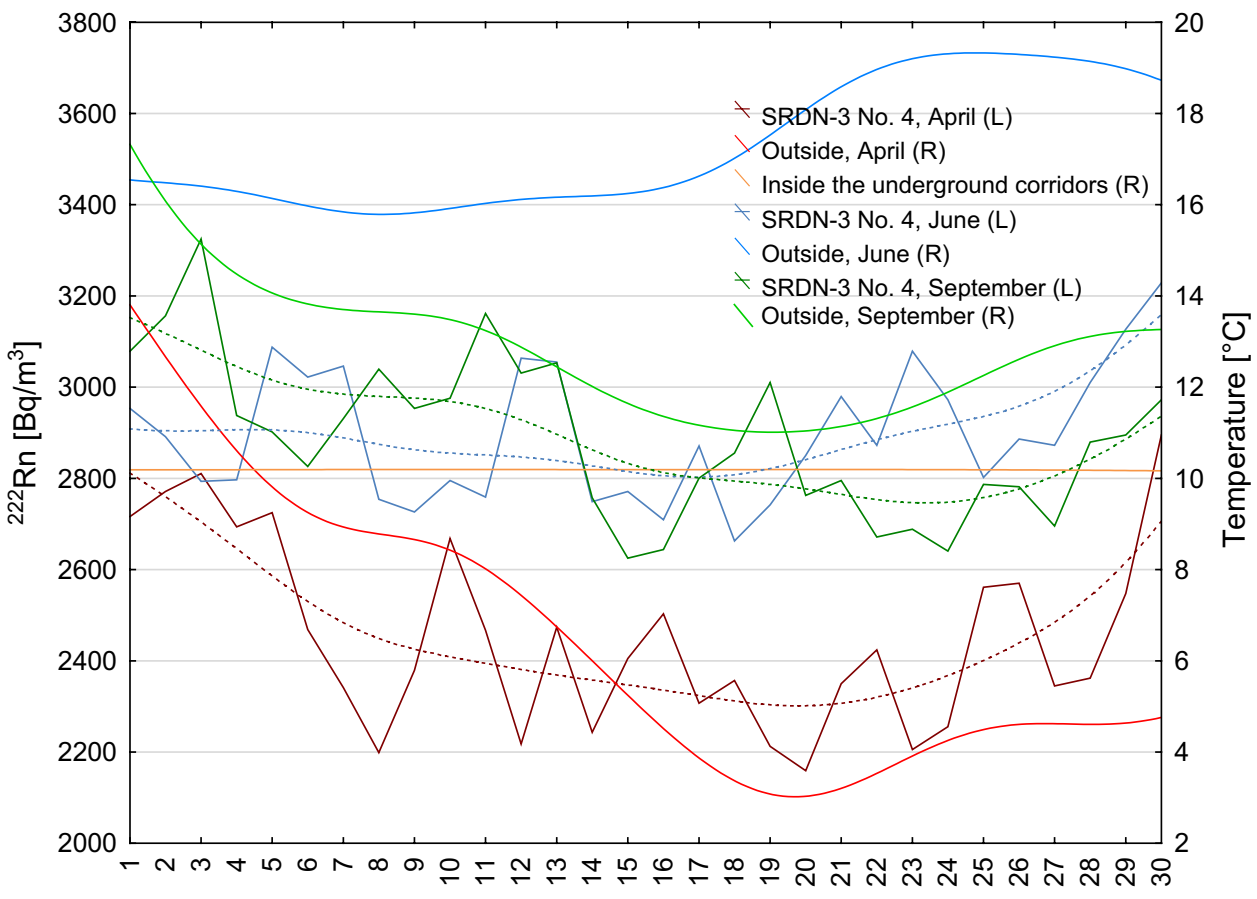

Day

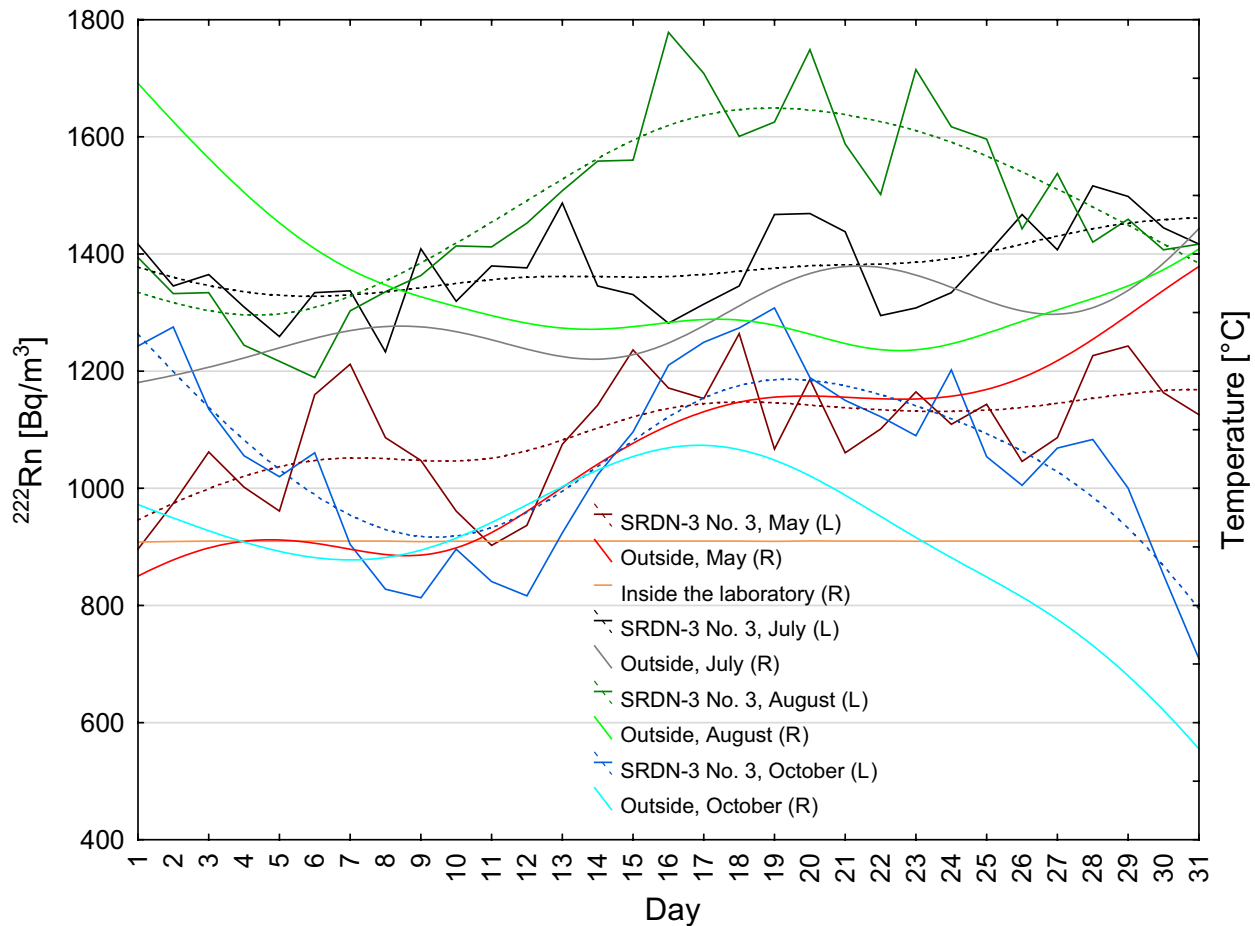


Fig. 8 Pattern of diurnal ${ }^{222} \mathrm{Rn}$ activity concentration changes in comparison with inside and outside temperature registered in May, July, August and October 2017 on second measuring point. Graph explanation: dashed line-average value of ${ }^{222} \mathrm{Rn}$ activity concentration with moving average fitting. $\mathrm{R}$-right y axis, $\mathrm{L}$ - left y axis

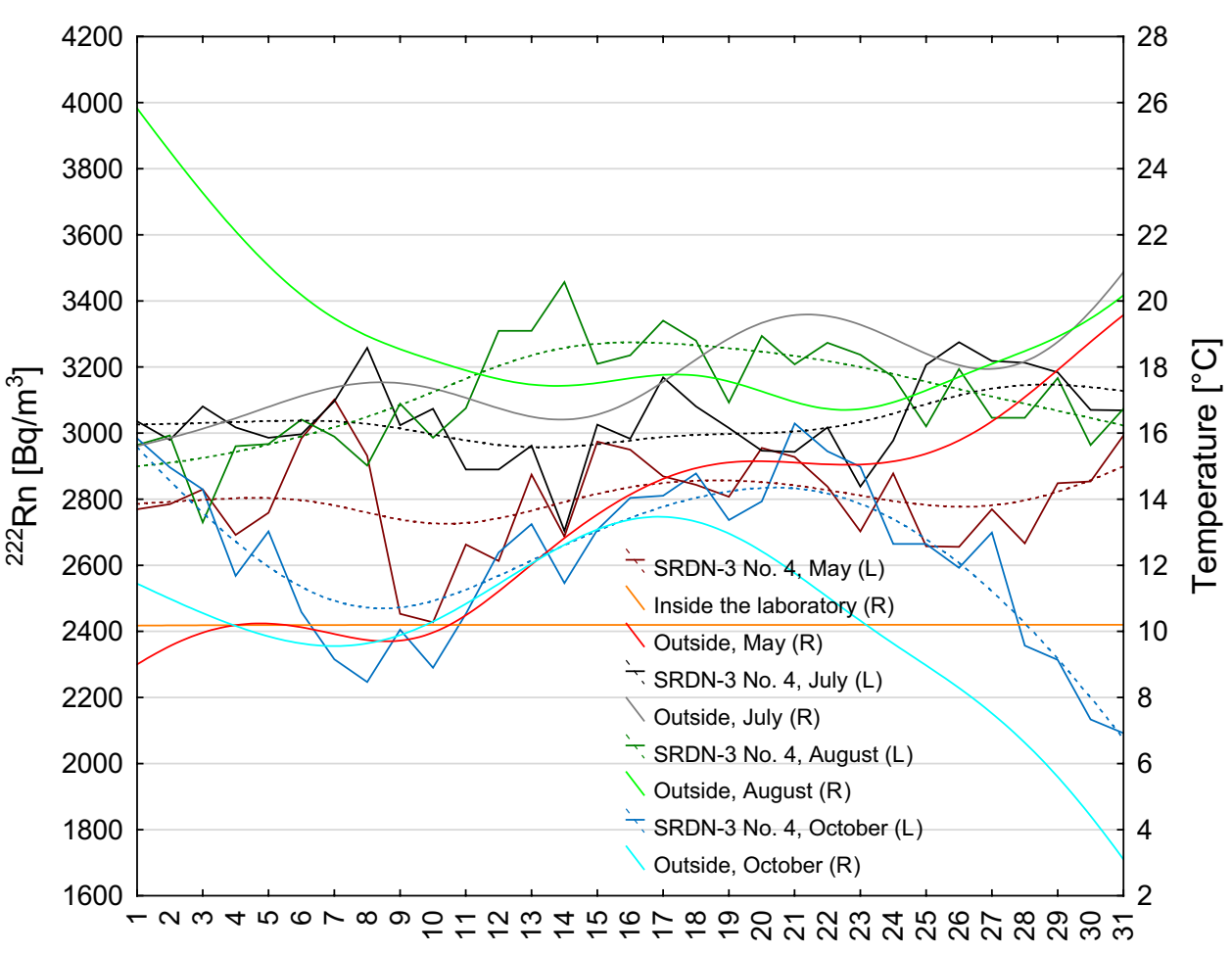

Day

Table 1 Basic descriptive statistics for the values of ${ }^{222} \mathrm{Rn}$ activity concentration registered between 2016 and 2017 at two measurement points in underground corridors under the cour d'honneur of Książ castle

\begin{tabular}{|c|c|c|c|c|c|c|c|c|}
\hline \multirow{3}{*}{$\begin{array}{l}\text { Number of } \\
\text { SRDN-3 probe }\end{array}$} & \multirow{3}{*}{$\begin{array}{l}\text { Year of meas- } \\
\text { urements }\end{array}$} & \multirow{2}{*}{$\begin{array}{l}\text { Number of } \\
\text { analysed data }\end{array}$} & \multicolumn{6}{|c|}{${ }^{222} \mathrm{Rn}$ activity concentration } \\
\hline & & & Average & Median & Minimum & Maximum & Interval & $\begin{array}{l}\text { Standard } \\
\text { deviation } \\
(1 \delta)\end{array}$ \\
\hline & & $(-)$ & $\left(\mathrm{Bq} / \mathrm{m}^{3}\right)$ & & & & & \\
\hline 3 & 2016 & 8760 & 976 & 950 & 91 & 2434 & 2343 & 366 \\
\hline 3 & 2017 & 8760 & 976 & 911 & 91 & 2434 & 2343 & 379 \\
\hline 4 & 2016 & 8760 & 2714 & 2668 & 1224 & 4772 & 3549 & 521 \\
\hline 4 & 2017 & 8760 & 2584 & 2544 & 1059 & 4442 & 3383 & 501 \\
\hline
\end{tabular}

\section{Results and discussion}

The analysis is based on 35,040 data collected uninterruptedly for 2 years at 2 measurement points (Table 1). One measurement point was set up in an excavation encased in concrete lining (SRDN-3 No. 3), while the other one-in a tunnel drilled in fractured rock mass (SRDN-3 No. 4). Both measurement points were about $100 \mathrm{~m}$ apart (Fig. 1). The analysis is supplemented with a discussion of the convection process occurring inside the two selected workings at Książ (Figs. 5, 6, 7, 8).

The collected data has been analysed in the context of seasonal variations, observed in the annual cycle (Figs. 3,
4), and short-term changes observed daily in transitional periods lasting from April to October (Figs. 5, 6, 7, 8). Seasonal changes in underground objects in Poland were first time described by Przylibski [86] in two caves, while the short-period changes were described by FijałkowskaLichwa and Przylibski [85].

During the year, ${ }^{222} \mathrm{Rn}$ activity concentrations are subject to almost identical fluctuations at both measurement sites (Figs. 3, 4).

Within the 2-year observation period (2016-2017), the ${ }^{222} \mathrm{Rn}$ activity concentrations recorded at site No. 1 (with reinforced concrete lining) were clearly lower. At the same time, mean annual values of ${ }^{222} \mathrm{Rn}$ activity concentration reached almost $1000 \mathrm{~Bq} / \mathrm{m}^{3}$ (Table 1). At measurement site 
Table 2 Basic descriptive statistics for ${ }^{222} \mathrm{Rn}$ activity concentration values registered in each month of two years of measurements registered between 2016 and 2017 at two measurement points in underground corridors under the the cour d'honneur of Książ castle

\begin{tabular}{|c|c|c|c|c|c|c|c|c|c|}
\hline \multirow{2}{*}{$\begin{array}{l}\text { Number of } \\
\text { SRDN-3 probe }\end{array}$} & \multirow[t]{3}{*}{ Month } & \multirow{3}{*}{$\begin{array}{l}\text { Year of } \\
\text { measure- } \\
\text { ments }\end{array}$} & \multirow{3}{*}{$\begin{array}{l}\text { Number of } \\
\text { analysed data } \\
(-)\end{array}$} & \multicolumn{6}{|c|}{${ }^{222} \mathrm{Rn}$ activity concentration } \\
\hline & & & & Average & Median & Minimum & Maximum & Interval & $\begin{array}{l}\text { Standard } \\
\text { deviation } \\
(1 \delta)\end{array}$ \\
\hline$(-)$ & & & & $\left(\mathrm{Bq} / \mathrm{m}^{3}\right)$ & & & & & \\
\hline 3 & January & 2016 & 744 & 643 & 637 & 91 & 1262 & 1172 & 184 \\
\hline 3 & & 2017 & 744 & 698 & 598 & 130 & 1145 & 1016 & 180 \\
\hline 4 & & 2016 & 744 & 2332 & 2338 & 1513 & 3370 & 1857 & 323 \\
\hline 4 & & 2017 & 744 & 2134 & 2111 & 1100 & 3122 & 2022 & 314 \\
\hline 3 & February & 2016 & 672 & 673 & 676 & 208 & 1262 & 1055 & 188 \\
\hline 3 & & 2017 & 672 & 662 & 637 & 169 & 1380 & 1211 & 185 \\
\hline 4 & & 2016 & 672 & 2357 & 2338 & 1389 & 3370 & 1981 & 327 \\
\hline 4 & & 2017 & 672 & 2276 & 2297 & 1348 & 3287 & 1939 & 350 \\
\hline 3 & March & 2016 & 744 & 766 & 755 & 286 & 1536 & 1250 & 199 \\
\hline 3 & & 2017 & 744 & 704 & 676 & 247 & 1340 & 1094 & 186 \\
\hline 4 & & 2016 & 744 & 2461 & 2462 & 1389 & 3576 & 2187 & 352 \\
\hline 4 & & 2017 & 744 & 2326 & 2338 & 1100 & 3493 & 2393 & 334 \\
\hline 3 & April & 2016 & 720 & 945 & 950 & 286 & 1848 & 1562 & 228 \\
\hline 3 & & 2017 & 720 & 815 & 794 & 169 & 1926 & 1758 & 247 \\
\hline 4 & & 2016 & 720 & 2798 & 2792 & 1554 & 4236 & 2682 & 415 \\
\hline 4 & & 2017 & 720 & 2454 & 2462 & 1389 & 3988 & 2600 & 386 \\
\hline 3 & May & 2016 & 744 & 1156 & 1145 & 403 & 2317 & 1914 & 290 \\
\hline 3 & & 2017 & 744 & 1096 & 1067 & 364 & 1926 & 1562 & 235 \\
\hline 4 & & 2016 & 744 & 2986 & 2998 & 1760 & 4360 & 2600 & 436 \\
\hline 4 & & 2017 & 744 & 2799 & 2792 & 1760 & 4112 & 2352 & 388 \\
\hline 3 & June & 2016 & 720 & 1408 & 1379 & 755 & 2434 & 1679 & 248 \\
\hline 3 & & 2017 & 720 & 1241 & 1223 & 481 & 2004 & 1523 & 237 \\
\hline 4 & & 2016 & 720 & 3251 & 3246 & 2132 & 4772 & 2641 & 384 \\
\hline 4 & & 2017 & 720 & 2898 & 2874 & 1678 & 4401 & 2723 & 379 \\
\hline 3 & July & 2016 & 744 & 1303 & 1301 & 559 & 2122 & 1562 & 249 \\
\hline 3 & & 2017 & 744 & 1376 & 1379 & 637 & 2161 & 1523 & 260 \\
\hline 4 & & 2016 & 744 & 3128 & 3122 & 2214 & 4442 & 2228 & 380 \\
\hline 4 & & 2017 & 744 & 3039 & 3039 & 1884 & 4442 & 2558 & 380 \\
\hline 3 & August & 2016 & 744 & 1301 & 1301 & 716 & 2122 & 1406 & 242 \\
\hline 3 & & 2017 & 744 & 1477 & 1458 & 755 & 2434 & 1679 & 294 \\
\hline 4 & & 2016 & 744 & 3111 & 3122 & 2049 & 4277 & 2228 & 372 \\
\hline 4 & & 2017 & 744 & 3117 & 3101 & 1760 & 4401 & 2641 & 409 \\
\hline 3 & September & 2016 & 720 & 1244 & 1223 & 520 & 2122 & 1601 & 273 \\
\hline 3 & & 2017 & 720 & 1256 & 1262 & 403 & 2200 & 1797 & 279 \\
\hline 4 & & 2016 & 720 & 2986 & 2998 & 1967 & 4195 & 2228 & 389 \\
\hline 4 & & 2017 & 720 & 2888 & 2874 & 1719 & 4195 & 2476 & 392 \\
\hline 3 & October & 2016 & 744 & 953 & 911 & 247 & 2004 & 1758 & 276 \\
\hline 3 & & 2017 & 744 & 1048 & 1028 & 325 & 2083 & 1758 & 270 \\
\hline 4 & & 2016 & 744 & 2699 & 2709 & 1430 & 4484 & 3053 & 408 \\
\hline 4 & & 2017 & 744 & 2619 & 2627 & 1471 & 3823 & 2352 & 424 \\
\hline 3 & November & 2016 & 720 & 695 & 676 & 208 & 1527 & 1319 & 193 \\
\hline 3 & & 2017 & 720 & 747 & 735 & 208 & 1458 & 1250 & 197 \\
\hline 4 & & 2016 & 720 & 2271 & 2297 & 1306 & 3411 & 2104 & 334 \\
\hline 4 & & 2017 & 720 & 2266 & 2255 & 1059 & 3452 & 2393 & 330 \\
\hline
\end{tabular}


Table 2 (continued)

\begin{tabular}{|c|c|c|c|c|c|c|c|c|c|}
\hline \multirow{2}{*}{$\begin{array}{l}\text { Number of } \\
\text { SRDN-3 probe }\end{array}$} & \multirow[t]{3}{*}{ Month } & \multirow{3}{*}{$\begin{array}{l}\text { Year of } \\
\text { measure- } \\
\text { ments }\end{array}$} & \multirow{3}{*}{$\begin{array}{l}\text { Number of } \\
\text { analysed data }\end{array}$} & \multicolumn{6}{|c|}{${ }^{222} \mathrm{Rn}$ activity concentration } \\
\hline & & & & Average & Median & Minimum & Maximum & Interval & $\begin{array}{l}\text { Standard } \\
\text { deviation } \\
\left(\begin{array}{ll}1 & \delta\end{array}\right)\end{array}$ \\
\hline$(-)$ & & & & $\left(\mathrm{Bq} / \mathrm{m}^{3}\right)$ & & & & & \\
\hline 3 & December & 2016 & 744 & 615 & 598 & 130 & 1223 & 1094 & 170 \\
\hline 3 & & 2017 & 744 & 657 & 657 & 91 & 1223 & 1133 & 179 \\
\hline 4 & & 2016 & 744 & 2168 & 2173 & 1224 & 3039 & 1816 & 310 \\
\hline 4 & & 2017 & 744 & 2171 & 2173 & 1348 & 3163 & 1816 & 315 \\
\hline
\end{tabular}

No. 2, in both 2016 and 2017 , mean annual values of ${ }^{222} \mathrm{Rn}$ activity concentration were more than twice as high and they exceeded $2500 \mathrm{~Bq} / \mathrm{m}^{3}$ (Table 1).

Higher values of ${ }^{222} \mathrm{Rn}$ activity concentration were recorded by both probes in late spring and in summer, i.e. from late April to early October (Table 2). Lower ${ }^{222} \mathrm{Rn}$ activity concentrations occurred in the cooler part of the year, i.e. from November to March/early April (Table 2).

Daily variations are clearly dependent on the seasonal changes (Figs. 3, 4). Any fluctuations in ${ }^{222} \mathrm{Rn}$ activity concentration values correspond to the periods of natural convective air exchange between the space interior and the atmosphere. The temperature inside the underground system under the cour d'honneur of Książ castle is stable regardless of the time of the day or the year, and it averages $10.2{ }^{\circ} \mathrm{C}$. The convection process is triggered suddenly at the moment of change (an increase or a decrease) of the atmospheric air temperature in relation to the mean temperature inside the underground space. The reference point for the occurring changes is the abovementioned constant temperature inside the space, i.e. $10.2^{\circ} \mathrm{C}$. An increase in the external temperature leads to fast accumulation of radon inside the space while its decrease causes rapid outflow of the air, together with the radon it contains, which results in maintaining a possibly constant concentration, until the moment of the next change in the temperature of the atmospheric air. As a result, higher and irregularly time-varying values of ${ }^{222} \mathrm{Rn}$ activity concentration are observed daily in the warmer part of the year. In the cooler seasons, much lower and irregularly varying ${ }^{222} \mathrm{Rn}$ activity concentration values were recorded on a daily basis (Figs. 5, 6, 7, 8).

The process of natural convective air exchange has been analysed based on daily changes in ${ }^{222} \mathrm{Rn}$ activity concentration in transitional periods, when air movement was very slow, hindered or even stopped. These periods occurred between April and early October (Figs. 5, 6, 7, 8).

The process of convective air movement was visible at each measurement site between April and October. Its pattern and character, regardless of the place and the year of measurements was comparable in the same months of measurements. Radon outflow from the underground space into the atmosphere took place in April. At that time, the temperature of the atmospheric air was $7{ }^{\circ} \mathrm{C}$ lower than the temperature inside the underground site (Figs. 5, 6). In May, June, and July, the temperature difference between the site interior and the atmosphere was from $2{ }^{\circ} \mathrm{C}$ to even $9{ }^{\circ} \mathrm{C}$. The significantly higher air temperature in relation to the mean temperature inside the underground site resulted in stopping the convection process and radon accumulation in the air stagnating inside the underground workings (Figs. 7, 8). This process demonstrates low permeability, both in the zone of insulated rock mass (site No. 1) and where it is fractured, weathered and intersected by faults (site No. 2), enabling air exchange with the atmosphere only during longer periods favourable to convection (November-March). The obtained measurement results indicate that air exchange with the atmosphere, regardless of the location of the measurement site, be it the zone of fractures (rock loosening) or rock mass insulation (poorly permeable coating) is strongly limited throughout the research site. In August, distinct radon accumulation occurred at both measurement points. This process was triggered instantaneously when the external temperature was $8{ }^{\circ} \mathrm{C}$ higher than the temperature inside the studied space (Figs. 7, 8). In September, the air exchange process was first halted and then it slowly restarted. The halt occurred at measurement site No. 1 between the first and the fifteenth day of the month. At that time, the temperature of the atmospheric air was $7{ }^{\circ} \mathrm{C}$ lower than the temperature inside the site (Fig. 5, 6). The air exchange did not occur until the second ten days of the month, when the temperature of the atmospheric air dropped to $1-3{ }^{\circ} \mathrm{C}$ below the temperature inside the studied space (Fig. 5). At measurement site No. 2, radon was transported outside throughout all the month of the observations. The process of natural convective air exchange was very slow owing to a small temperature difference between the space interior and the atmosphere, which was about $3{ }^{\circ} \mathrm{C}$ (Fig. 6). At this time, the recorded values of ${ }^{222} \mathrm{Rn}$ activity concentration decreased slightly, from about $3000 \mathrm{~Bq} / \mathrm{m}^{3}$ to slightly less than $2800 \mathrm{~Bq} / \mathrm{m}^{3}$ (Fig. 6). In October, at both measurement sites (No. 1 and No. 2), 
the convection process was halted when the atmospheric air temperature was about $3{ }^{\circ} \mathrm{C}$ higher than the temperature inside the underground space. At that time, radon was accumulated inside. A drop in the atmospheric air temperature to at least $2{ }^{\circ} \mathrm{C}$ below the temperature inside the underground space $\left(10.2{ }^{\circ} \mathrm{C}\right)$ triggered convective air movement. The air containing accumulated radon was transported outside (Figs. 7, 8).

A distinct area of radon accumulation inside the studied space is the zone of fractured non-insulated rock mass (Figs. 3, 4, 6, 8). The causes of the occurrence of such high radon concentrations are not entirely obvious and require further analyses. Supposedly, it is the pressure change related to strike-slip movements of particular rock blocks in the fault zones of the orogen which is quite significant here. Rock movement, notably in dislocation zones being radon migration paths, may significantly affect the changes in the size of radon flux reaching the workings (Table 1).

\section{Conclusions}

Based on long-term measurements of ${ }^{222} \mathrm{Rn}$ activity concentration conducted between 1 January 2016 and 31 December 2017 in the air of two selected underground workings under the cour d'honneur of Książ castle, the author assessed a possibility of applying reinforced concrete lining as a barrier limiting (insulating) radon flux from the surrounding rock into the workings. The assessment was based on analysing the differences in the characteristics of both seasonal and short-term (daily) changes in ${ }^{222} \mathrm{Rn}$ activity concentration at two representative points inside the underground space —one located within weathered rock mass and the other-in an excavation insulated with reinforced concrete lining.

It was found out that ${ }^{222} \mathrm{Rn}$ activity concentrations undergo seasonal changes both in the excavation insulated with a lining structure and in the fractured non-insulated rock mass. The patterns of these changes are almost identical. During the year, distinctly higher values of ${ }^{222} \mathrm{Rn}$ activity concentration occur at both sites from April till early October. Clearly lower values are recorded in the remaining months. The difference between the absolute values of ${ }^{222} \mathrm{Rn}$ activity concentrations recorded in these periods is over twofold.

The ${ }^{222} \mathrm{Rn}$ activity concentrations recorded in the two workings are subject to irregular short-term (daily) changes, particularly apparent in so-called transitional periods. This observation confirms the fact that daily changes are determined by seasonal changes. The observed daily periods when the concentration increases or decreases are very short. Also, differences between the absolute values of ${ }^{222} \mathrm{Rn}$ activity concentrations recorded in these periods are small (at the level of threshold value calculated for SRDN-3 device measurement uncertainty). As for the excavation insulated from the rock mass directly by reinforced concrete lining, the apparent irregularity may be due to the limited permeability of the rock mass and the restrained possibility of its displacement. Additionally, the lining structure can also significantly insulate the excavation against the impact of external factors such as humidity or temperature. In such a case, air movement triggered (within a short time) by the convection process may be additionally constrained in the transitional period lasting from April to early October, not only because of the too small and short-term daily temperature difference between the underground space interior and the atmosphere, but also owing to the lower permeability of the rock mass. In April, owing to the drop in the atmospheric air temperature below the temperature inside the underground workings, radon is carried out into the atmosphere. In May, June, and July, the outdoor temperature was markedly higher than the temperature inside the workings, which led to a halt in the convection process and accumulation of radon in the stagnating air inside the space. In August, rapid and distinct radon accumulation occurred inside the underground workings at Książ. In the first half of September, convection is stopped and then slowly activated again in the latter half of the month. In October, a small rise or drop in the atmospheric air temperature to $2-3{ }^{\circ} \mathrm{C}$ above or below the mean temperature inside the workings results in the respective halt or activation of the convection process. The unconstrained and unlimited flow of air does not start until November and then it continues till early April, when the mean daily temperature of the atmospheric air gets considerably lower than the mean temperature inside the underground workings at Książ (below $10.2{ }^{\circ} \mathrm{C}$ ). The larger the temperature difference, the more efficient the described process is.

The application of a reinforced concrete lining structure insulating the fractured and absorptive rock mass is relevant for the assessment of the ${ }^{222} \mathrm{Rn}$ activity concentrations recorded inside the workings, but it does not affect the character of changes in ${ }^{222} \mathrm{Rn}$ activity concentration either within a long (at least annual) or a short (a day or an hour) observation cycle. The lining structure is a barrier limiting the radon flux from the surrounding rocks into the workings, and it can also slightly affect the mechanism of radon flow from the rock into the underground space due to factors like reduced porosity of the rock medium. The insulation of the excavation roof and sidewalls has a negligible effect on the course of the convection process, which is determined chiefly by the difference between the temperature of the atmospheric air and the air inside the underground space.

The mean annual values of ${ }^{222} \mathrm{Rn}$ activity concentration are about $1000 \mathrm{~Bq} / \mathrm{m}^{3}$ in the tunnel fitted with reinforced concrete lining and slightly more than $2500 \mathrm{~Bq} / \mathrm{m}^{3}$ in the fractured rock zone. In the light of radiological protection regulations specified in the EU Council Directive of 5 
December 2013 [64] establishing basic security standards for hazards of ionizing radiation exposure, which have been adopted by Polish law, these values are considerably higher than the reference level for radon concentrations in enclosed spaces and workplaces, set at the yearly average of $300 \mathrm{~Bq} /$ $\mathrm{m}^{3}$ [64]. In view of exceeding this reference level, precautionary measures should be taken, aimed at lowering the risk through effective ventilation or limiting the exposure by reducing the time spent inside the underground space (especially by employees whose duties require prolonged stays inside the space between spring and early autumn).

Acknowledgements The research was co-financed from funds allocated to scientific research or development and the related projects contributing to the professional development of young scientists and $\mathrm{Ph} . \mathrm{D}$. students at the Faculty of Civil Engineering, granted in 2017 (Project No. 0402/0004/17).

\section{Compliance with ethical standards}

Conflict of interest The author declares that there is no conflict of interest.

Open Access This article is licensed under a Creative Commons Attribution 4.0 International License, which permits use, sharing, adaptation, distribution and reproduction in any medium or format, as long as you give appropriate credit to the original author(s) and the source, provide a link to the Creative Commons licence, and indicate if changes were made. The images or other third party material in this article are included in the article's Creative Commons licence, unless indicated otherwise in a credit line to the material. If material is not included in the article's Creative Commons licence and your intended use is not permitted by statutory regulation or exceeds the permitted use, you will need to obtain permission directly from the copyright holder. To view a copy of this licence, visit http://creativecommons.org/licenses/by/4.0/.

\section{References}

1. Commission Recommendation of 21 February 1990 on the protection of the public against indoor exposure to radon. European Communities. 90/143/Euratom

2. Unscear 2000. United Nations Scientific Committee on the Effects of Atomic Radiation, Sources and effects of ionizing radiation. Report to the General Assembly, with Scientific Annexes, United Nations, New York

3. Waligórski M (2010) PAA information on nuclear safety and radiological protection in Poland in 2009. In: Biuletyn informacyjny Państwowej Agencji Atomistyki, 2(80), Państwowa Agencja Atomistyki, Warszawa (in Polish)

4. Chruścielewski W, Olszewski J (2000) Radon in the tourist facility of underground adits 9 and $9 \mathrm{a}$ in Kowary.In: Materiały konferencyjne "Radon w środowisku", Kraków 14-15 June 2000, (abstract) (in Polish)

5. Olszewski J, Chruścielewski W, Jankowski J (2005) Radon on underground tourist routes in Poland. Int Congr Ser 1276:360-361

6. Olszewski J, Zmyślony M, Wrzesień M, Walczak K (2015) Occurrence of radon in Polish underground tourist routes. Med Pr 66(4):557-563 (in Polish)
7. Olszewski J (2006) Exposure to radon along underground tourist routes. In: Radon w środowisku życia, pracy i nauki mieszkańców Dolnego Śląska, pp 55-62 (in Polish)

8. Gillmore GK, Sperrin M, Phillips P, Denman A (2000) Radon hazards, geology and exposure of caves users: a case and some theoretical perspectives. Ecotoxicol Environ Saf 46:279-288

9. Gillmore GK, Phillips P, Denman A, Sperrin M, Pearce G (2001) Radon levels in abandoned metalliferous mines, Devon, Southwest England. Ecotoxicol Environ Saf 49:281-292

10. Gillmore G, Gharib AH, Denman A, Phillips P, Bridge D (2011) Radon concentrations in abandoned mines, Cumbria, UK: safety implications for industrial archaeologists. Natu Hazards Earth Syst Sci 11:1311-1318

11. Komosa A (2005) Assessment of radon concentrations near Lublin. Radiochemistry Department Experience in this field. Materiały konferencyjne, Raport Nr 1967/AP:12-13 (abstract) (in Polish)

12. Labidi S, Essafi F, Mahjoubi H (2006) Estimation of the radiological risk related to the presence of radon-222 in a hydrotherapy centre in Tunisia. J Radiol Prot 26:309-316

13. Skowronek J (2006) Radon hazard in mines. In: Radon w środowisku życia, pracy i nauki mieszkańców Dolnego Śląska, Wrocław, pp 48-54 (in Polish)

14. Font LL, Baixeras C, Moreno V (2008) Indoor radon levels in underground workplaces of Catalonia, Spain. Radiat Meas 43:467-470

15. Kávási N, Somlai J, Szeiler G, Szabó B, Schafer I, Kovács T (2010) Estimation of effective doses to cavers based on radon measurements carried out in seven caves of the Bakony Mountains in Hungary. Radiat Meas 45(9):1068-1071

16. Kisiel J, Budzanowski M, Dorda J, Kozak K, Mazur J, Mietelski JW, Puchalska M, Tomankiewicz E, Zalewska A (2010) Measurements of natural radioactivity in the salt cavern of the Polkowice-Sieroszowice copper mine. Acta Phys Polonica B 41(7):1813-1819

17. Anjos RM, Umisedo N, Da Silva AAR, Estellita L, Rizzotto M, Yoshimura EM, Velasco H, Santos AMA (2010) Occupational exposure to radon and natural gamma radiation in the La Carolina, a former gold mine in San Luis Province, Argentina. J Environ Radioact 101:153-158

18. Yoon S, Chang B-U, Kim Y, Byun Y-I, Yun J-Y (2010) Indoor radon distribution of subway stations in a Korean major city. $\mathbf{J}$ Environ Radioact 101:304-308

19. Wysocka M (2011) Radon in Jurassic caves of the KrakówCzęstochowa Upland. Geochem J 45:447-453

20. Tchorz-Trzeciakiewicz DE, Parkitny T (2015) Radon as a tracer of daily, seasonal and spatial air movements in the Underground Tourist Route "Coal Mine" (SW Poland). J Environ Radioact 149:90-98

21. Fijałkowska-Lichwa L (2014) Short-term radon activity concentration changes along the Underground Educational Tourist Route in the Old Uranium Mine in Kletno (Sudety Mts., SW Poland). J Environ Radioact 135:25-35

22. Fijałkowska-Lichwa L (2016) Extremely high radon activity concentration in two adits of the abandoned uranium mine 'Podgórze' in Kowary (Sudety Mts., Poland). J Environ Radioact 165:13-23

23. Fijałkowska-Lichwa L, Przylibski TA (2016) First radon measurements and occupational exposure assessments in underground geodynamic laboratory the Polish Academy of Sciences. J Environ Radioact 165:253-269

24. Fijałkowska-Lichwa L, Przylibski TA (2020) A comprehensive characteristic of ${ }^{222} \mathrm{Rn}$ activity concentration changes and ionising radiation exposure in newly discovered parts of Bear Cave in Kletno, Poland. Radiation Protect Dosimetry. https://doi. org/10.1093/rpd/ncz263 
25. Sahu P, Panigrahi DC, Mishra DP (2016) A comprehensive review on sources of radon and factors affecting radon concentration in underground uranium mines. Environ Earth Sci 75:617

26. Liu C, Zeng Z (2018) The CR-39 etching optimization and measurement for radon in China Jinping Underground Laboratory. J Radioanal Nucl Chem 318(2):1369-1377

27. Strzelecki R, Wołkowicz S (1993) Geological control on radon emanations. Nukleonika 38(4):109-120

28. Strzelecki R, Wołkowicz S, Szewczyk J, Lewandowski P (1993) Radioecological maps of Poland. Part I: Gamma radiation dose rates in Poland: Map of caesium concentrations in Poland, Scale 1: 750,000. Państwowy Instytut Geologiczny, Warszawa (in Polish)

29. Strzelecki R, Wołkowicz S, Szewczyk J, Lewandowski P (1994) Radioecological maps of Poland. Part II: Maps of uranium, thorium and potassium concentrations in Poland. Państwowy Instytut Geologiczny, Warszawa (in Polish)

30. Strzelecki R, Wołkowicz S, Nałęcz T (2000) Radioactive elements and the problem of radioecologal hazards in towns of the Sudetic region. Przegląd Geologiczny 48(12):1139-1150 (in Polish)

31. Wołkowicz S, (ed) (2007) Radon potential of the Sudetes and selected geological units of the Fore-Sudetic block. In: Potencjał radonowy Sudetów wraz z wyznaczeniem obszarów występowania potencjalnie leczniczych wód radonowych, Rozdział 1, Państwowy Instytut Geologiczny, Warszawa (in Polish)

32. Przylibski TA (2001) Radon and its daughter products behaviour in the air of an underground tourist route in the former arsenic and gold mine in Złoty Stok (Sudety Mountains, SW Poland). J Environ Radioact 57:87-103

33. Przylibski TA (2015) Radon research in Poland: a review. Solid State Phenom 238:90-115

34. Przylibski TA (2018) Radon: a radioactive therapeutic element. In: Radon, health and natural hazards. Geological Society, Special Publications, vol 451, pp 209-236. https://doi.org/https://doi. org/10.1144/SP451.7

35. Emsley J (1997) Chemistry. A guide to the elements. Translated by Stanisław Kłosowicz, Wydawnictwo Naukowe PWN, Warszawa (in Polish)

36. Clements WE, Wilkenning MH (1974) Atmospheric pressure effect on ${ }^{222} \mathrm{Rn}$ transport across the earth-air interface. J Geophys Res 79(33):5025-5029

37. Cothern CR, Smith JE Jr (eds) (1987) Environmental radon. Plenum Press, New York

38. Chibowski S, Komosa A (2001) Radon concentration in basements of old town buildings in the Lublin region, Poland. J Radioanal Nucl Chem 247(1):53-56

39. Dueñas $C$, Fernández MC, Cañete $S(2005){ }^{222}$ Rn concentrations and radiation exposure levels in the Nerja Cave. Radiat Meas 40:630-632

40. Hakl J, Hunyadi I, Csige I, Géczy G, Lénárt L, Várhegyi A (1997) Radon transport phenomena studied in karst caves-international experiences on radon levels and exposures. Radiat Meas 28(1-6):675-684

41. Steinitz G, Begin ZB, Gazit-Yaari N (2003) A statistically significant relation between Rn flux and weak earthquakes in the Dead Sea Rift Valley. Geology 31:505-508

42. Richon P, Perrier F, Sabroux J-C, Trique M, Ferry C, Voisin V, Pili E (2005) Spatial and time variations of radon-222 concentration in the atmosphere of a dead-end horizontal tunnel. J Environ Radioact 78(2): 179-198

43. Richon P, Klinger Y, Tapponnier P, Li C-X, Van der Woerd J, Perrier $F$ (2010) Measuring radon flux across active faults: relevance of excavating and possibility of satellite discharges. Radiat Meas 45:211-218

44. Zapotoczna-Sytek G, Mamont-Cieśla K, Rybarczyk T (2012) Natural radioactivity of building materials, including autoclaved aerated concrete (AAC). Przegląd Budowlany 7-8:39-42 (in Polish)

45. Tsapalov A, Kovler K (2016) Revisiting the concept for evaluation of radon protective properties of building insulation materials. Build Environ 95:182-188

46. Ubysz A, Maj M, Musiał M, Ubysz J (2017) Radon-occurrence and health risks in civil engineering. Procedia Eng 172:1184-1189

47. Soniya R, Abraham S, Khandaker MU, Jojo PJ (2020) Investigation of diffusive transport of radon through bricks. Radiat Phys Chem. https://doi.org/10.1016/j.radphyschem.2020.108955

48. Gandolfo G, Lepore L, Pepperosa A, Remetti R, Franci D (2017) Radiation protection considerations on radon and building materials radioactivity in Near Zero Energy Buildings. Energy Procedia 140:13-22

49. Jiránek M, Hůlka J (2001) Applicability of various insulating materials for radon barriers. Sci Total Environ 272(1-3):79-84

50. Boardman C, R., Glass, S., V. (2015) Basement radon entry and stack driven moisture infiltration reduced by active soil depressurization. Build Environ 85:220-232

51. Keller G, Hoffmann B, Feigenspan T (2001) Radon permeability and radon exhalation of building materials. Sci Total Environ 272(1-3):85-89

52. Kumar A, Chauhan RP (2014) Active and passive measurements of radon diffusion coefficient from building construction materials. Environ Earth Sci 72:251-257. https://doi.org/10.1007/s1266 5-013-2951-5

53. Stajic JM, Nikezic D (2015) Measurement of radon exhalation rates from some building materials used in Serbian construction. J Radioanal Nucl Chem 303:1943-1947. https://doi.org/10.1007/ s10967-014-3726-5

54. Bala P, Kumar V, Mehra R (2017) Measurement of radon exhalation rate in various building materials and soil samples. J Earth Syst Sci 126:31. https://doi.org/10.1007/s12040-017-0797-z

55. Kuzmanović P, Todorović N, Filipović Petrović L et al (2020) Radioactivity of building materials in Serbia and assessment of radiological hazard of gamma radiation and radon exhalation. $\mathbf{J}$ Radioanal Nucl Chem 324:1077-1087. https://doi.org/10.1007/ s10967-020-07130-8

56. Kumar M, Sharma N, Sarin A (2018) Prediction of indoor radon/ thoron concentration in a model room from exhalation rates of building materials for different ventilation rates. Acta Geophys 66:1249-1255. https://doi.org/10.1007/s11600-018-0159-5

57. Corrêa JN, Silva ACM, Paschuk SA, Barreto ARC, Denyak V, Schelin HR, Narloch DC, Hashimoto Y, Martin AC (2020) Thickness of radon emitting layer in building materials. Radiat Phys Chem 172:108786. https://doi.org/10.1016/j.radphysche m.2020.108786

58. Lamparska J (1998) Mysteries. Castles. Underground systems. A guidebook you have never seen, Wrocław (in Polish)

59. Kalarus J (2001) The Underground Książ. Cryptonym Riese, Nowa Ruda (in Polish)

60. Kruszyński P (2004) Underground structures in the Owl Mountains and Książ Castle, Wałbrzych (in Polish)

61. Pawlikowska M (2008) Książ castle-mysteries of the past as a chance to revive tourist attendance. In: Dziedzictwo kulturoweochrona i adaptacja jako szansa na rozwój, Uniwersytet Łódzki (in Polish)

62. Rostkowski J (2004) Książ castle—a forgotten mystery, Warszawa (in Polish)

63. Law of 29 November 2000 r. Atomic Law (obwieszczenie Marszałka Sejmu Rzeczypospolitej Polskiej z dnia 11 września 2019 r. w sprawie ogłoszenia jednolitego tekstu ustawy-Dz. U. 2019 poz. 1792; 2000 (in Polish)

64. EU Council Directive 2013/59/Euratom of 5 December 2013 laying down basic safety standards for protection against the dangers arising from exposure to ionising radiation. and repealing 
Directives 89/618/Euratom. 90/641/Euratom. 96/29/Euratom. 97/43/Euratom and 2003/122/ Euratom. Official Journal of the European Union. 17.1.2014, L 13/1-L 13/73; 2013

65. Kaczorowski M (1999) The long water-tube clinometer in Książ Geophysical Station. Promot Works Artif Sat 34(3):171-191

66. Kaczorowski M (1999) The results of preliminary tilt measurements by use of the long water-tube clinometer in Książ Geophysical Station. Artif Satell 34(3):193-201

67. Kaczorowski M (2009) Discussion on strong non-tidal signals registered by horizontal pendulums and water tube tiltmeters in Geodynamic Laboratory of PAS in Książ. Acta Geodyn Geomater 3(155):369-381

68. Kaczorowski M, Olszak T, Walo J, Barlik M (2012) Research of absolute gravity variations on Geodynamic Laboratory in Książ in the period 2007-2011. In:Artificial Satellites. Planetary Geodesy, pp 169-176

69. Kasza D, Kaczorowski M, Zdunek R, Wronowski R (2014) The damage of Książ castle architecture in relation to routes of recognized tectonic faults and indications of recent tectonic activity of Świebodzice Depression orogen-Central Sudetes, SW Poland. Acta Geodyn Geomater 113(175):225-234

70. Kasza D, Kowalski A, Wojewoda J, Kaczorowski M (2018) Indicators of recent geodynamic activity in the Książ Castle area (Świebodzice Unit, Sudetes) in the light of structural analysis and geodetic measurements.In: Przylibski TA, Kasza D (eds) XVII Conference of PhD Students and Young Scientists, E3S Web of Conferences 29. https://doi.org/https://doi.org/10.1051/e3sco $\mathrm{nf} / 20182900021$ (in Polish)

71. Przylibski TA, Kaczorowski M, Fijałkowska-Lichwa L, Kasza D, Zdunek R, Wronowski R (2020) Testing of ${ }^{222} \mathrm{Rn}$ application for recognizing tectonic events observed on water-tube tiltmeters in underground Geodynamic Laboratory of Space Research Centre at Książ (the Sudetes, SW Poland). Appl Radiat Isotopes 163:108967

72. Industrial Standard BN-79/0434-09. 1979. Tunnel lining structures, Corridor and chamber workings, Concrete lining structure. Requirements and investigations (in Polish)

73. Wichur A (2009) Issues of designing long-term underground excavation lining. Górnictwo i Geoinżynieria, 33, 3/1 (in Polish)

74. Wichur A, Gruszka R (2000) New standards for designing long-term underground corridor excavation lining. Uczelniane Wydawnictwa Naukowo-Dydaktyczne, pp 595-604 (in Polish)

75. Majcherczyk T, Małkowski P, Niedbalski Z (2006) Rock mass movements and lining response in the process of rock destruction around corridor workings based on in situ research. Katedra Geomechaniki, Budownictwa i Geotechniki AGH, 130 (in Polish)

76. Majcherczyk T, Niedbalski Z, Małkowski P (2010) Strengthening the lining of corridor workings in intense mining and geological conditions. Górnictwo i Geoinżynieria 34(2) (in Polish)

77. Sienicka K, Zagożdżon PP (2010) Detailed geological survey of "Osówka" site ("Riese" complex). In: Dzieje górnictwa—element europejskiego dziedzictwa kultury, vol 3, pp 415-430 (in Polish)

78. Kasza D (2012) Possibilties of using GIS applications for geological mapping illustrated by underground site "Włodarz" in the Owl Mountains. In: Prace Naukowe Instytutu Górnictwa Politechniki Wrocławskiej, 135, Studia i Materiały, p 42 (in Polish)

79. Teisseyre H (1956) The Świebodzice depression as a geological unit. Biul Inst Geol 106:1-60 (in Polish)

80. Porębski SJ (1981) Świebodzice succession (Upper DevonianLower Carboniferous, western Sudetes): a prograding, mass-flow dominated fan-delta complex. Geologia Sudetica 16(1):99-190

81. Wojewoda J (2016) The Świebodzice unit (Sudety Mts.)—structural anomalies in the course of river valleys. In: VI Polska Konferencja Sedymentologiczna POKOS 6-“Granice Sedymentologii", pp 145-148 (in Polish)

82. Wojewoda J (2016) On the need for the second edition of the 'Detailed Geologic Map of the Sudetes' in 125000 scale-examples of revised description of geological structure based on a lidar background for a numerical model of terrain surface. Przegląd Geologiczny 64(9):597-603 (in Polish)

83. Website, meteoblue.com, 10.10.2018 (in Polish)

84. Przylibski TA, Bartak J, Kochowska E, Fijałkowska-Lichwa L, Kozak K, Mazur J (2010) New SRDN-3 probes with a semiconductor detector for measuring radon activity concentration in underground spaces. J Radioanal Nuclear Chem 289:599-609

85. Fijałkowska-Lichwa L, Przylibski TA (2011) Short term ${ }^{222} \mathrm{Rn}$ activity concentration changes in underground spaces with limited air exchange with the atmosphere. Nat Hazards Earth Syst Sci 11:1179-1188

86. Przylibski TA (1999) Radon concentration changes in the air of two caves in Poland. J Environ Radioact 45(1):81-94

87. Website, eloblog.pl, 04. 01. 2019 (in Polish)

88. Żelaźniewicz A, Aleksandrowski P (2008) Tectonic subdivision of Poland: southwestern Poland. Przegląd Geologiczny 56(10):904911 (in Polish)

Publisher's Note Springer Nature remains neutral with regard to jurisdictional claims in published maps and institutional affiliations. 